\title{
TOEIC LISTENING AND READING JAKO SOUČÁST HODNOCENÍ STUDENTŮ TECHNICKÉ UNIVERZITY V LIBERCI
}

\author{
Stanislava Pavlíková \\ Technická univerzita v Liberci, Ekonomická fakulta, Katedra cizích jazyků, \\ Studentská 1402/2, 46117 Liberec 1, Česká Republika \\ e-mail: stanislava.pavlikova@tul.cz
}

\begin{abstract}
Abstrakt
V článku je nejprve uvedena charakteristika testu TOEIC v kontextu testování studentů na Technické univerzitě v Liberci, Katedře cizích jazyků. Dále je popsána analýza výsledků těchto testů získaných v období let 2015 až 2020. Analýza byla zaměřena na porovnání skóre, kterých uchazeči dosáhli v sekcích testu ve čtení a poslechu. Výsledky šetření jsou podnětem $\mathrm{k}$ návrhu na úpravy sylabů jazykových kurzů tak, abychom se zaměřili na vyváženost učebních aktivit a podpoření slabších dovedností studentů, kterými jsou problémy ve čtení s porozuměním. Dalším zdrojem informací k aktualizaci učebních plánů jsou názory studentů, kteří test TOEIC i jazykový kurz absolvovali v roce 2019.
\end{abstract}

\section{Keywords}

TOEIC; Reading comprehension; Test results; Reading strategies; Reading activities.

\section{Úvod}

Obsah kurzů cizího jazyka by měl zohledňovat potřeby studentů z hlediska jejich budoucího uplatnění na trhu práce, měl by vycházet ze současných didaktických poznatků a využívat moderní informační technologie. Podnětem k průběžné aktualizaci sylabů jsou také studijní výsledky účastníků kurzů, které jsou hodnoceny prostřednictvím písemných nebo ústních zkoušek a testů. Důležitým zdrojem informací pro úpravu učebních plánů může být i zpětná vazba studentů po ukončení jazykového kurzu a absolvování testů.

\section{$1 \quad$ Cíl studie}

Cílem studie je na základě analýzy výsledků testování TOEIC Listening and Reading navrhnout úpravu sylabů jazykových kurzů tak, aby byly vyváženě podpořeny jazykové dovednosti studentů a aby byly kompenzovány př́ípadné nedostatky znalostí absolventi̊ těchto testů. Bude přihlédnuto také k výsledkům dotazníkového šetření, jehož respondenti byli studenti, kteří již kurzy cizího jazyka i test TOEIC absolvovali.

\section{Mezinárodně uznávaná zkouška TOEIC}

\subsection{TOEIC Listening and Reading na TUL}

Kromě pravidelných zápočtových a klasifikovaných jazykových testů poskytuje univerzita svým studentům možnost skládat zkoušky z anglického jazyka a získat mezinárodně platný certifikát TOEIC (Test of English for International Communication). Tento certifikát ověřuje aktuální úroveň znalosti angličtiny uchazeče a zvyšuje hodnotu jeho životopisu na konkurenčním trhu práce. Dle dat společnosti ETS Global [1] je také nejčastěji požadovanou zkouškou v pracovním prostředí. Každý rok test TOEIC absolvuje více než sedm milionů lidí a certifikát uznávají tisíce podniků po celém světě jako objektivní hodnocení znalostí 
angličtiny. V roce 2015 se Technická univerzita v Liberci (TUL) dohodla na obchodním partnerství s nizozemskou společností ETS Global a stala se jedním z jejích preferovaných spolupracovníků. V rámci této spolupráce je anglická sekce Katedry cizích jazyků TUL akreditovaným pracovištěm pro organizaci administrace testů TOEIC Listening and Reading. Cílové skupiny účastníků testů zahrnují studenty, kteří se připravují na vstup do pracovního prostředí nebo chtějí studovat $\mathrm{v}$ zahraničí $\mathrm{v}$ angličtině (např. studium $\mathrm{v}$ rámci programu Erasmus+), a také ty, kteří již pracují v různých oblastech řízení, prodeje a technologií v rámci mezinárodního obchodu. Mezi tyto cílové skupiny patří také ti, kteří používají angličtinu při pracovních činnostech a navazují mezinárodní spolupráci na konferencích a veletrzích. V akademickém roce 2014/2015 bylo první testování na Technické univerzitě $\mathrm{v}$ Liberci nabídnuto všem studentům $\mathrm{v}$ jejich posledním ročníku bakalářského studia na Ekonomické fakultě. $\mathrm{V}$ letech následujících se testování zúčastnili i zájemci $\mathrm{z}$ technických fakult (Fakulta mechatroniky a Fakulta strojní).

\subsection{Charakteristika testu TOEIC}

Test se zaměruje na hodnocení jazykových znalostí potřebných v mezinárodním pracovním prostředí a skóre odráží schopnost komunikovat v různých obchodních situacích při provádění běžných pracovních činností. Skóre se pohybuje od 10 do 990 bodů a odpovídá Společnému evropskému referenčnímu rámci, který hodnotí jazykové znalosti v rozmezí od A1 do $\mathrm{C} 1$. Každý test se skládá ze dvou částí a trvá dvě hodiny. Poslechová část trvá 45 minut a následuje čtení, na které je časový limit 75 minut. Obě části jsou tvořeny dvěma sty otázek, ke kterým jsou uvedeny čtyři možné odpovědi, z nichž studenti označí na odpovědním archu tu, kterou považují za správnou. V obou sekcích jsou úlohy řazeny od jednoduchých k obtížnějším. Na základě vyhodnocení odpovědí získá kandidát tři skóre; jedno z poslechové části, jedno ze čtení, a to v rozsahu od 5 do 495 bodů. Celkové skóre se skládá ze součtu sekcí poslechu a čtení [1]. Testové otázky simulují situace v reálném životě, které se objevují v obchodním prostředí, a výsledky testů jsou podkladem pro podrobný slovní popis jazykových schopností testovaného. Tento popis je uveden na certifikátu.

Dalším aspektem, který bychom měli zmínit, je rozmanitost textů, které se u zkoušky objevují. Struktura TOEIC vychází z praktických potřeb obchodní komunikace a testuje např́klad dovednosti studenta dokončit jednotlivé věty i texty. $\mathrm{V}$ poslechové části jsou zahrnuty výroky popisující fotografie, krátké konverzace mezi dvěma i více účastníky a nahrávky monologů - např́iklad hlasových zpráv nebo částí přednášek. V sekci čtení s porozuměním uchazeči hledají informace $\mathrm{v}$ různých dokumentech, jako jsou zápisy ze schůzí, interní sdělení, objednávky zboží, stvrzenky, články z časopisů, novinové články, emaily a jejich přílohy, informační letáky, motivační dopisy, nájemní smlouvy nebo různé druhy reklamních materiálů.

Výsledky testu uvedené v bodech lze převést na evropské úrovně SERR (Společný evropský referenční rámec pro jazyky) dle Tab. 1.

Tab. 1: Referenční tabulka

\begin{tabular}{|c|c|c|c|}
\hline Body celkem & Poslech & Čtení & SERR \\
\hline 945 & 490 & 455 & $\mathrm{C} 1$ \\
\hline 785 & 400 & 385 & $\mathrm{~B} 2$ \\
\hline 550 & 275 & 275 & $\mathrm{~B} 1$ \\
\hline 225 & 110 & 115 & $\mathrm{~A} 2$ \\
\hline 120 & 60 & 60 & $\mathrm{~A} 1$ \\
\hline
\end{tabular}

Zdroj: [2] 


\subsection{Charakteristika souboru}

Během necelých šesti let jsme získali výsledky testů 245 studentů závěrečného ročníku bakalářského programu na Ekonomické fakultě TUL. Všichni studenti před testem TOEIC absolvovali pět semestrů obchodní angličtiny na Katedře cizích jazyků.

Počty uchazečů v jednotlivých letech jsou uvedeny v Tab. 2.

Tab. 2: Počty testovaných studenti̊

Zdroj: Vlastni

\begin{tabular}{|l|c|}
\hline Rok & Počet testovaných studentů \\
\hline 2015 & 110 \\
\hline 2016 & 71 \\
\hline 2017 & 34 \\
\hline 2018 & 10 \\
\hline 2019 & 16 \\
\hline 2020 & 4 \\
\hline Celkem & $\mathbf{2 4 5}$ \\
\hline
\end{tabular}

\subsection{Analýza výsledků testů}

Výsledky testů TOEIC našich studentů za období necelých šesti let jsme se rozhodli analyzovat a získané informace využít při přípravě budoucích jazykových kurzů.

Z každého termínu testování obdrží škola přehlednou tabulku uvádějící skóre jednotlivých studentů v části čtení, poslech a celkový počet bodů. Dále je za celý termín uveden nejlepší a nejhorší dosažený výsledek a průměrná hodnota celého termínu.

Průměrné hodnoty jednotlivých termínů testování se během let téměř nemění. Vždy studenti dosahují úrovní B1 až $\mathrm{C} 1$ (převedeno na SERR). Pokud ovšem porovnáme výsledky částí poslechu a čtení, zjistíme negativní vývoj výsledků ve čtení s porozuměním.

Vycházíme ze skutečnosti, že $\mathrm{v}$ obou částech testu mohou studenti dosáhnout stejného maximálního skóre (495 bodů). Proto je snadné porovnat výsledky čtení a poslechu u jednotlivých studentů a poté vypočítat průměrnou hodnotu rozdílu v každém termínu testování i za každý rok. Průměrné skóre zůstává v průběhu let stejné, ale v každém akademickém roce dosáhli studenti lepšího skóre v poslechové části. Negativní rozdíl mezi částí čtení a poslech se však během let výrazně zvyšuje. Tab. 3 uvádí konkrétní hodnoty dosažené v jednotlivých letech.

Tab. 3: Rozdíl mezi částí poslech a čtení v bodech

\begin{tabular}{|c|c|}
\hline Rok & Rozdíl mezi poslechem a čtením (body) \\
\hline 2015 & 34 \\
\hline 2016 & 38 \\
\hline 2017 & 44 \\
\hline 2018 & 58 \\
\hline 2019 & 65 \\
\hline 2020 & 48 \\
\hline
\end{tabular}

Zdroj: Vlastni

Z výše uvedeného vyplývá skutečnost, že celkové hodnocení jazykových znalostí studentů orientovat se vanglickém pracovním prostředí po absolvování jazykového kurzu 
v bakalářském programu studia zůstává během let na stejné úrovni. Pokud se nemění celkové průměrné hodnoty výsledků testů, pak lze ale předpokládat, že se studenti zlepšují v poslechu, ale zhoršují ve čtení.

V akademickém roce 2020/2021 se před přechodem na distanční výuku zúčastnili testu TOEIC jen čtyři studenti, proto má údaj z tohoto jednoho termínu malou vypovídací hodnotu.

\subsection{Dotazníkové šetřrení}

V roce 2019 dosáhl průměrný rozdíl ve skóre mezi poslechem čtením nejvyšší hodnoty - 65 bodů. Proto nás zajímal názor na problematiku čtení těch studenti̊, kteří absolvovali náš kurz angličtiny $\mathrm{i}$ test TOEIC. Jednalo se o 16 studentů a ti byli elektronicky požádáni o zodpovězení tří otevřených otázek zaměřených na problematiku čtení. Níže jsou otázky uvedeny včetně odpovědí získaných od 12 respondentů. Výroky studentů citované bez jazykové úpravy jsou seřazeny od nejčetnějších k nejméně často se vyskytujícím:

1. Co bylo při čtení snadné, co obtížné a proč? (Pokud si vzpomenete na konkrétní úlohy nebo jen obecně)

- U čtení mi přišlo nejhorší málo času. Za mne bylo nejobtížnější vše stihnout $\mathrm{v}$ časovém limitu.

- Z mého pohledu byl spíše poslech těžší, ale u čtení jsem měl problém s př́liš dlouhými texty, což bylo pro mě jakožto pomalého čtenáře obrovský ,„̌rrout času“ tudíž jsem asi $20+$ otázek nestihnul.

- Při čtení byla náročná zvyšující se časová náročnost, na první pětadvacítku mi stačilo deset patnáct minut, na poslední bylo potřeba skoro 30 minut.

- Jednotlivým textům se dalo dobře rozumět, ale těžší mi přišly úlohy, kde byly tři různé texty. Tam bylo obtížnější se zorientovat.

- Je to poměrně dlouhé, takže ke konci už není tak jednoduché se plně soustředit.

- Dle mého už bylo těžké se soustředit po tom dlouhém poslechu, navíc některé texty byly dlouhé a musela jsem je číst vícekrát. Doplňování slov do vět bylo dle mého celkem jednoduché a nepotřebovala jsem na to tolik času.

2. Jaké aktivity na seminářích angličtiny by pomohly studentům ve zlepšení čtení?

- Asi procvičovat podobné úlohy.

- Možná se více zaměřit na slovní zásobu.

- Podle mě se ale čtení dá dobře trénovat i doma, mně spíše přijde důležité trénovat na semináŕích mluvení.

- Netuším, v angličtině si čtu a na internetu se dost času pohybuji v anglickém prostředí, což hodně pomáhá, ale co se týče seminářŭ, nevím.

- Více se zabývat čtením, ne jen neustálé diskuze. I když máme cvičení na čtení, máme ho přečíst jen rychle (scan reading) a poté o tom diskutovat.

3. Proč podle Vašeho názoru studenti dosahují na nižší body ve čtení než v poslechu?

- Myslím, že je to hlavně, protože v dnešní době všichni koukáme na filmy a seriály $\mathrm{v}$ angličtině, posloucháme anglické písničky, proto s poslechem nemáme takový problém. Naopak s angličtinou v písemné podobě se asi tolik nesetkáváme. 
- Osobně mám z poslechu větší respekt kvůli tomu, že se musím soustředit v ten jeden daný moment, jinak mám smůlu, ale je pravda, že poslechové úlohy nejsou tak rozvinuté, co se týče délky a složitosti textu, bývají značně jednodušší.

- Opět tím, že se v hodinách spíše diskutuje.

Většina studentů uvedla, že pro ně bylo obtížné stihnout úlohy v části čtení s porozuměním v časovém limitu. Dále měli problém se soustředěním se při práci s delšími texty, některým chyběla slovní zásoba nebo pocit'ovali nedostatek zkušeností s obdobnými úlohami. V další části textu budou uvedeny návrhy aktivit, které lze zahrnout do budoucích sylabů jazykových kurzů $\mathrm{s}$ ohledem na výše uvedená zjištění a se záměrem rozvíjet čtenářské dovednosti budoucích ekonomů.

\section{$4 \quad$ Návrh na úpravu sylabů}

V současné době je na semináŕích cizích jazyků kladen důraz na aktivizaci studentů ke komunikaci převážně ústní formou $\mathrm{v}$ diskuzích, př́ípadových studiích nebo např́íklad v prezentacích. Čtení textů bývá často zadáváno jako součást domácí prrípravy studentů se záměrem co nejefektivněji využít kontaktní hodiny cizího jazyka k prŕmé komunikaci v jazyce. Mimo semináře ale nejsou studenti časově limitováni, a proto si neprocvičují dostatečně strategie potřebné k rychlému vyhledávání klíčových informací v textu.

Efektivní práce $s$ textem je důležitá při studiu nejen ve školním kontextu, ale i během celé kariéry v pracovním prostředí a během celoživotního učení. Pokud vezmeme v úvahu i výsledky dosažené ve čtenářské části TOEIC, je zřejmé, že by studenti měli procvičovat klíčové strategie čtení potřebné k identifikaci hlavních myšlenek textu (scanning), pochopení kontextu nebo vyhledání specifické informace (skimming). Tyto techniky čtení by se měly procvičovat $\mathrm{v}$ každém jazykovém kurzu bez ohledu na to, zda studenti plánují skládat zkoušku TOEIC či ne. Čtení s porozuměním je náročná aktivita zvláště pro studenty cizího jazyka. Obecně lze čtení s porozuměním definovat jako dovednost čtenáře ,dešifrovat text, tj. nalézt v něm klíčové pojmy a poznatky a postihnout vztahy mezi nimi““ [3].

Čtenářské strategie jsou vědomé a promyšlené postupy, které čtenáři pomáhají, aby porozuměl danému textu. Zde se uplatňuje čtenářova metakognice (přemýšlení o myšlenkových postupech) [4]. Cílem nácviku čtenářských strategií je osvojení si jich do takové míry, aby byly používány automaticky, aniž by si čtenář jejich aplikaci uvědomoval. Pokud se tyto strategie správně a dostatečně procvičují, mohou se stát čtenářskými dovednostmi [5].

\subsection{Aktivity zaměřené na rozvoj čtenářských dovedností}

Každá čtenářská aktivita by měla sestávat z následujících tř́ částí:

a) Úvodní část motivující studenty k přečtení textu. Zahrnuje aktivaci stávajících znalostí a slovní zásoby studentů. $\mathrm{V}$ prrípadě potřeby by měla být představena nová slova nebo jazykové struktury, aby byla zajištěna připravenost studentů ke čtení.

b) Čtenářská aktivita je obvykle prováděna jako druh úkolu, který je třeba splnit, aby se studenti soustředili a četli s určitým účelem.

c) V navazující aktivitě lze čtení integrovat s dalšími jazykovými dovednostmi, např́íklad diskusí na téma obsažené ve čtenářském úkolu nebo psaní, např. zpráva nebo shrnutí.

V reálném životě se důvody, proč text čteme, velmi liší. Proto bychom měli čtenářské aktivity měnit podle typu textu a účelu jeho čtení. Zapojením studentů do různých čtenářských aktivit a rozvoje jejich dovedností, jako je porozumění výslovně nebo implicitně uváděným 
informacím, odvozování významu i používání dřive neznámých lexikálních pojmů, porozumění pojmovému významu slov, porozumění komunikační hodnotě vět, porozumění vztahům ve větě a mezi jednotlivými částmi textu prostřednictvím lexikálních a gramatických prostředků, lze výrazně zlepšit interpretaci textu, identifikaci hlavních informací, rozlišení hlavní myšlenky od podpůrných detailů a shrnutí textu [6].

Výběr textů, které doplňují jazykové učebnice, pro činnosti související s rozvojem čtení je pro učitele důležitým úkolem. Na tuto volbu má vliv několik kritéríi. Měli bychom zvážit, zda je obsah vhodný, zajímavý a motivující, zda jej můžeme použít k rozvoji čtenářských kompetencí studentů konkrétní jazykové úrovně a zda je blízký reálným situacím. Pro výuku obchodní angličtiny jsou nejčastějšími texty dopisy, e-maily, zprávy, různé typy reklamních materiálů, smlouvy a další právní dokumenty, stejně jako články v novinách a časopisech, prezentace podniků a výrobků na internetu, se kterými se studenti při své budoucí práci setkají.

Při prŕpravě čtenářských aktivit si mohou učitelé vybrat ze seznamu, který poskytli Hughes et al. [7]:

- Odpovězte na otázky týkající se textu.

- Označte tvrzení jako pravdivé nebo nepravdivé. Opravte nepravdivé tvrzení.

- Položte svému partnerovi tři otázky na základě textu.

- Shrňte přečtený text pro vašeho partnera.

- Dohodněte se se svým partnerem na třech hlavních myšlenkách uvedených v textu.

- Doplňte věty př́slušným slovem.

- Změňte uspořádání textu. (Studenti uvedou do správného pořadí věty/odstavce, přímou řeč konverzace nebo nadpisy jednotlivých odstavců).

- Dle textu doplňte graf/tabulku/diagram

- Přečtěte si texty a doplňte chybějící informace (kombinace různých zdrojů informací)

- Vymyslete si vlastní název článku

Příklady dalších kreativních nápadů, jak používat texty zejména v prostředí třídy [8]:

- Rozšíření krátkého jednoduchého textu: Studenti přidají přídavné jméno před každé podstatné jméno / př́íslovce ke každému slovesu atd.

- Zkrácení textu. Úkolem studentů je zredukovat text na přesně určený počet slov.

- Rekonstrukce textu. Učitel připraví seznam klíčových slov z textu $\mathrm{v}$ neuspořádaném pořadí. Ve tř́idě si studenti nejprve přečtou text. Poté jsou požádáni, aby vložili klíčová slova zpět do správného pořadí, aniž by se podívali na text.

- Transformace textu. Studenti transformují text například tak, že převypráví příběh v první osobě, nikoli ve třetí osobě, nebo místo novinového článku uvedou novinku jako televizní zprávu.

- Př́íprava textového kvízu. Studenti nejprve přečtou text. Poté ve skupinách připraví zadaný počet otázek $\mathrm{k}$ textu, na které by měla odpovědět jiná skupina, aniž by textu do znovu nahlédla. Tuto aktivitu lze uspořádat jako soutěž a vítězí skupina $\mathrm{s}$ nejvíce správnými odpověd'mi. 


\subsection{Využití internetových zdrojů a aplikací}

Výbornými zdroji aktuálních materiálů ke čtení jsou např́klad dva weby „Breaking News English.com“ a „News in Levels“. Učitelé angličtiny mohou využít všech dostupných materiálů $\mathrm{k}$ plánu výuky spolu $\mathrm{s}$ texty na základě nejnovějších zpráv. Tyto materiály jsou $\mathrm{k}$ dispozici i se zvukovými soubory v několika úrovních jazykových znalostí.

$\mathrm{K}$ nácviku čtení $\mathrm{v}$ časovém limitu jsou vhodné různé aplikace, kde autor cvičení může omezit dobu na jejich vypracování. Pak jsou takto vytvořené aktivity vhodné pro kontaktní výuku na semináŕích i mimo ni. Vysokoškolští studenti mohou v rámci svých prezentací dokonce vytvořit cvičení pro ostatní studenty ve skupině (např. v aplikaci Kahoot). Další vhodné internetové nástroje jsou Padlet, HotPotatoes, Canva nebo Spreeder.

\section{Závěr}

Výsledky testů TOEIC získané během posledních šesti let upozornily na problémy týkající se čtenářských dovedností studentů Ekonomické fakulty TUL. Analýza výpovědí studentů, kteří test i jazykový kurz absolvovali, naznačuje, jakým způsobem by mohly být sylaby jazykových kurzů modifikovány. Tento článek se proto zabývá komplexní problematikou čtenářských dovedností a navrhuje možné studijní aktivity na podporu rozvoje čtení s porozuměním. Zda bude mít větší pozornost věnovaná čtenářským aktivitám požadovaný pozitivní dopad na studijní výsledky absolventů kurzů, bude možné vyhodnotit až na základě budoucích výsledků testů. Sběr těchto potřebných dat a jejich analýza si vyžádá delší časový horizont.

\section{Literatura}

[1] ETS: TOEIC Listening and Reading Test. [online]. [cit. 2021-08-13]. Dostupné z WWW: https://www.ets.org/toeic/listening-reading

[2] ETS: Score Usage. [online]. [cit. 2021-08-13]. Dostupné z WWW: https://www.etsglobal.org/fx/en/help-center/score-usage/are-toeic-listening-andreading-test-scores-mapped-cefr

[3] MAŇÁK, J.; ŠVEC, V.: Výukové metody. 1. vyd. Paido, Brno, 2003. ISBN 80-7315039-5.

[4] KARBALAEI, A.: A Comparison of the Metacognitive Reading Strategies Used by EFL and ESL Readers. The Reading Matrix. 2010, Vol. 10, Issue 2, pp. 165-180. Dostupné z WWW: https://readingmatrix.com/articles/sept_2010/alireza_karbalaei.pdf

[5] WHITCROFT, L.: Čtenářská gramotnost čtenářské strategie 1. [online]. 2010. [cit. 2021-08-20]. Dostupné z WWW: $\underline{\text { http://www.ctenarska- }}$ gramotnost.cz/kategorie/ctenarska-gramotnost/cg-strategie

[6] GRELlET, F.: Developing Reading Skills: A Practical Guide to Reading Comprehension Exercises. Cambridge University Press, Cambridge, 1990. ISBN 978-0521-28364-9.

[7] HUGHES, G. S.; MOATE, J.; RAATIKAINEN, T.: Practical classroom English. Oxford University Press, Oxford, 2007. ISBN 978-019-4422-796.

[8] BUSYTEACHER_ADMIN: What to Do with Reading Texts: 10 Creative Ways. [online]. [cit. 2021-08-14]. Dostupné z WWW: https://busyteacher.org/2748-what-todo-with-reading-texts-10-creative-ways.html

Ing. Stanislava Pavlíková, Ph.D. 


\section{TOEIC LISTENING AND READING AS PART OF STUDENT'S EVALUATION AT THE TECHNICAL UNIVERSITY OF LIBEREC}

The first part of the article presents the characteristics of the TOEIC test in the context of testing students at the Department of Foreign Languages of the Technical University of Liberec. The analysis of the test results obtained in the period from 2015 to 2020 is described in the next part. The analysis was focused on the comparison of the scores that the candidates achieved in the reading and listening sections of the test. The results of the survey are meant to give a stimulus to propose a modification of the syllabi of language courses so that they focus on the balance of learning activities and support of weaker skills of students, i.e., problems in reading comprehension. The opinions of students who took the TOEIC test and the language course in 2019 are another source of information serving to update the syllabi.

\section{TOEIC LISTENING AND READING ALS BESTANDTEIL DER BEWERTUNG DER STUDIERENDEN DER TECHNISCHEN UNIVERSITÄT LIBEREC}

In diesem Artikel geht es als Erstes um die Charakteristik des TOEIC-Tests im Kontext des Testens der Studenten an der Technischen Universität Liberec, Lehrstuhl für Fremdsprachen. Weiter wird die Analyse der in den Jahren 2015 - 2020 erlangten Ergebnisse dieser Teste dargelegt. Die Analyse war auf den Vergleich der Punktzahlen ausgelegt, welche die Bewerber in den Sektionen der Teste, d. h. in den Bereichen Lese- und Hörverstehen erreicht haben. Die Ergebnisse der Untersuchung bilden die Grundlage für den Entwurf für Verbesserungen der Syllabi der Sprachkurse, und zwar dergestalt, dass wir uns auf die Ausgewogenheit der Lehraktivitäten und der Unterstützung der schwächer ausgeformten Fertigkeiten der Studierenden konzentrieren. Schwächen finden wir besonders im Leseverstehen. Eine weitere Quelle der Informationen zur Aktualisierung der Lehrpläne sind die Meinungen der Studenten, welche den TEOIC-Test sowie den Sprachkurs im Jahre 2019 absolviert haben.

\section{TOEIC LISTENING AND READING JAKO ELEMENT OCENY STUDENTÓW UNIWERSYTETU TECHNICZNEGO W LIBERCU}

W artykule w pierwszej kolejności opisano charakterystykę egzaminu TOEIC w kontekście egzaminowania studentów na Uniwersytecie Technicznym w Libercu, w Katedrze Języków Obcych. Następnie opisano analizę wyników przeprowadzonych egzaminów uzyskanych w okresie 2015-2020. Analiza miała na celu porównanie wyników, jakie zostały osiągnięte w ramach egzaminu oceniającego umiejętność czytania i słuchania. Wyniki badań stanowią bodziec do zaproponowania zmiany sylabusów kursów językowych $\mathrm{w}$ taki sposób, by skupiały się one na równowadze elementów dydaktycznych i wspomagały gorsze umiejętności studentów, do których należą problemy $\mathrm{z}$ czytaniem ze zrozumieniem. Kolejnym źródłem informacji dla aktualizacji planów nauczania są opinie studentów, którzy egzamin TOEIC i kurs językowy odbyli w 2019 roku. 